\title{
Sugarcane's chemical ripeners: effects on growth and gas exchange of Citharexylum myrianthum, a Brazilian native tree species
}

\author{
Marina Alves Gavassi ${ }^{1 *}$, Allan Lopes Bacha ${ }^{2}$, Cárita Liberato do Amaral ${ }^{2}$, Leonardo Bianco de Carvalho ${ }^{3}$ \\ and Pedro Luis da Costa Aguiar Alves ${ }^{2}$
}

${ }^{1}$ Universidade Estadual Paulista "Júlio de Mesquita Filho", Instituto de Biociências, Departamento de Botânica. Avenida 24 A, 1515, Bela Vista, 13506-900 - Rio Claro - SP, Brazil

2Universidade Estadual Paulista "Júlio de Mesquita Filho", Departamento de Biologia Aplicada à Agropecuária. Via de Acesso Prof. Paulo Donato Castellane, s/n Bairro Rural. 14884-900 Jaboticabal- SP, Brazil

${ }^{3}$ Universidade Estadual Paulista "Júlio de Mesquita Filho", Departamento de Fitossanidade. Via de Acesso Prof. Paulo Donato Castellane, s/n Bairro Rural. 14884900 Jaboticabal- SP, Brazil

\section{*Corresponding author: marinagavassi@hotmail.com}

\section{Abstract}

Chemical ripeners are being used to anticipate the ripening process of sugarcane. These products act in specific enzyme or protein systems of plants, altering their functionality. However, these products can seriously affect the development of non-target species. In light of the proximity of permanent preservation areas to sugarcane plantations, we aimed at understanding the effect of simulated drift of chemical ripeners on 18-month age seedlings of Citharexylum myrianthum, a Brazilian native tree species. The experiment was conducted under semi-controlled conditions using a randomized block design with six replications. Treatments consisted of a $6 \times 2$ factorial arrangement, corresponding to six concentrations of glyphosate and sulfometuron-methyl, equivalent to $0,5,15,30,45$, and $60 \%$ of commercial dose recommended for sugarcane. Plant height, stem diameter, number of leaves, total chlorophyll content, chlorophyll a fluorescence, and gas exchange were measured at 7, 30, and 60 days after application (DAA). The leaf area and dry mass of plants were also measured at the end of the experimental period (60 DAA). Both ripeners caused visual symptoms of phytointoxication in C. myrianthum, which were accompanied by alterations in gas exchange until 30 DAA. At $60 \mathrm{DAA}$, all plants treated with glyphosate recovered their photosynthetic capacity, without detrimental effect on their initial development, while those treated with $60 \%$ of sulfometuron-methyl showed limited growth in height coupled to super sprout due to the death of apical meristem. Despite no significant difference in total dry mass, the development of these plants was affected.

Keywords: Brazilian native species; drift; glyphosate; sulfometuron-methyl; reforestation.

Abbreviations: ALS_acetolactate-synthase; $A_{-} \mathrm{CO}_{2}$ assimilation rate; $\mathrm{Chl}$ _Total chlorophyll content; $C_{\mathrm{i}}$ internal $\mathrm{CO}_{2}$ concentration; DAA_Days after application; DAP_Days after planting; Diam_Stem diameter; DML_Dry mass of leaves; $E_{-}$transpiration rate; $F_{\mathrm{v}} / F_{\mathrm{m} \_}$Chlorophyll $a$ fluorescence; $g_{\mathrm{s} \_}$stomatal conductance; PSII_Photosystem II.

Introduction

Despite techniques related to vegetal improvement representing the main means of increasing production, the expansion of agricultural boundaries continues to be used for this purpose (Nori et al., 2013). However, in the absence of environmental planning beforehand, this expansion causes forest fragmentation and loss of biodiversity (Potapov et al., 2017). Reductions in forests result in damage to the ecosystems and may compromise some essential processes to maintain the biological diversity of these areas, such as: stabilization of watercourse banks; the surface and subsurface filtration of water, and mitigation of sediment transport to waterways. As a result of the commitment of these processes, the local temperature of waters as well as their quality and quantity end up being altered, influencing all local fauna and flora (Mori et al., 2013). Consequently, increase in initiatives for restoring degraded areas has been observed in the last decades (Jellinek et al., 2013), mainly in the riparian areas of Brazilian states, basically due to two factors: raised awareness in society and legal requirements. Thus, the tree species Citharexylum myrianthum Cham. (Verbenaceae) is highlighted, since it is widely used in areas of reforestation in these regions. This species originates from Dense Ombrophilous Forests - Atlantic Forest, and it is also found in riparian forests of the semideciduous seasonal forest (Lorenzi, 1992). This species is commonly observed in early stages of ecological succession of forests, and its fruits are appreciated by local fauna (Vasconcelo and Aguiar, 1982), becoming important component in the regeneration of degraded areas. Some of passive reforestation areas, especially riparian forests, are inside or close to properties in which agricultural crops dominate, with sugarcane being the main emerging crop in various Brazilian states (Conab, 
2017). Depending on the climate conditions for sugarcane maturation process, plant vegetative growth can be stimulated at the expense of sucrose accumulation, implying the production of lower quality material or even its scarcity (Viana et al., 2008). In order to bring forward the ripening process and help in planning sugarcane harvest, chemical ripeners have been used, many of which are herbicides applied in sub-doses that act in specific enzyme or protein systems of plants by altering their functionality (Alvarez et al., 2012). Among chemical products used as ripeners, glyphosate stands out, being widely used as growth inhibitor, as well as sulfometuron-methyl, which is a vegetal growth regulator (Correia and Leite, 2012).

The sugar alcohol sector has been seeking to improve its applications of phytosanitary products as a way of reducing spending, and with this aim, aerial applications are being widely used for spraying herbicides and ripeners. However, they may increase the risk of these products drifting into non-target species (Gelmini et al., 1988). By definition, drift is the displacement of the applied product out of the desired target, a phenomenon that can occur due to the wind action, runoff or even volatilization of product diluent (Andef, 2017). Possibly, because of drift, part of ripeners and herbicides applied to sugarcane crops can reach non-target plants in neighboring areas when products were not applied properly.

Thus, with the hypothesis that the glyphosate and sulfometuron-methyl drift may negatively affect the initial growth of $C$. myrianthum, the objective of this work was to evaluate the effects of simulated glyphosate and sulfometuron-methyl drift on the gas exchange and initial growth characteristics of $C$. myrianthum.

\section{Results}

Symptoms of glyphosate and sulfometuron-methyl application on Citharexylum myrianthum

At 7 days after the application (DAA), visual effects of phytointoxication caused by both products were observed. The glyphosate introduced chlorosis into the first pair of fully expanded leaves in all of the treatments with more than $30 \%$ of commercial concentration (Figure 1). Regarding sulfometuron-methyl drift, the initial leaf coloring changed to yellow-bronze with $5 \%$ of commercial concentration upwards (Figure 2).

\section{Citharexylum myrianthum biometric characteristics after application of chemicals}

At the end of the experimental period, with the exception of the dry mass of leaves (DML), there was no significant difference between the treatments that received the application of glyphosate for any of the biometric characteristics assessed (Table 1). For DML, 15\% and 30\% concentration treatments were the ones with the highest values, statistically differing from the $45 \%$ treatment, which presented a $32 \%$ lower DML value than the $30 \%$ treatment; however, it should be noted that this difference was not reflected in the total dry mass of the plant (Table 1).

For the sulfometuron-methyl, as the concentration applied increased, there was increased number of leaves per plant, resulting from the loss in apical dominance. The plants treated with $60 \%$ of the commercial concentration presented death of the apical meristem (Figure 3-E) resulting in $287.8 \%$ more leaves than the control $(0 \%)$, which obtained the lowest value, together with the $5 \%$ concentration (Table 1). In spite of this, the leaf area was not altered between the treatments, indicating super sprout (Figure 3-A to 3-E). The $5 \%$ treatment was the one with the greatest height, significantly differing from the $15 \%$ and $60 \%$ concentrations, which caused reductions of $23.5 \%$ and $30.9 \%$, respectively. The $15 \%$ treatment was also the one that resulted in the smallest stem diameter, with a difference for the $5 \%$ and $0 \%$ concentrations. For the dry mass of plants, no significant difference was found between the concentrations tested (Table 1)

\section{Citharexylum myrianthum photosynthetic characteristics}

Plants that received $15 \%$ glyphosate application showed higher $F_{\mathrm{v}} / F_{\mathrm{m}}$ values, differing from the highest concentrations but not from the lowest ones (Table 2). For the net $\mathrm{CO}_{2}$ assimilation rate, the effect was the opposite, in that the $30 \%$ and $45 \%$ doses resulted in greater carbon sequestration in relation to the two lowest doses tested, differing statistically. Also, the $60 \%$ treatment caused a $39.3 \%$ reduction in stomatal conductance compared to the $30 \%$ treatment, which resulted in a higher value for the characteristic and differed from all of the treatments except the $45 \%$ one. For internal carbon, the $5 \%$ treatment resulted in the lowest value, only equaling the $60 \%$ treatment. The total chlorophyll content and transpiration rate did not present any significant difference between the treatments (Table 2).

Still at 7 DAA, plants that received the sulfometuronmethyl treatment in any concentration showed reductions in $F_{\mathrm{v}} / F_{\mathrm{m}}$, but not in total chlorophyll content (Table 2). In relation to the net assimilation rate, plants that received $5 \%$ of this product differed significantly from treatments with the three highest concentrations, with a $59 \%$ higher value than the plants that received $60 \%$ of the ripener concentration. For the other characteristics of gas exchange (stomatal conductance, internal carbon, and transpiration rate), all treatments showed pattern of results similar to the control, in which values were highest and differed from the treatments that received the $15 \%$ concentrations or more of sulfometuron-methyl, presenting reduction in the parameters indicated (Table 2).

From 30 DAA onwards, there was no difference between the treatments, independent of the product applied, both for $F_{\mathrm{v}} / F_{\mathrm{m}}$ and for total chlorophyll content (Table 3). Regarding the gas exchange there was no difference in the $\mathrm{CO}_{2}$ sequestration rate for glyphosate treatments. However, this product resulted in gains of up to $38.8 \%$ for transpiration in relation to the control in concentrations equal to or higher than $15 \%$ (Table 3). For stomatal conductance, only the $30 \%$ and $60 \%$ treatments differed statistically from the control, which presented the lowest level for this variable. For internal $\mathrm{CO}_{2}$ concentration, again the plants that were treated with a $30 \%$ concentration of the product obtained the highest values, with significant 
Table 1. Effect of different concentrations of glyphosate (Glizmax $192 \mathrm{~g}$ e.a. ha ${ }^{-1}$ ) and sulfometuron-methyl (Curavial $15 \mathrm{~g}$ e.a. ha $\left.{ }^{1}\right)$ to Citharexylum myrianthum on plant height $(\mathrm{cm})$, stem diameter (Diam - mm), number of leaves (N. Leaves), leaf area (L. Area $\mathrm{cm}^{2}$ ), dry mass of leaves (DMLeaf $-\mathrm{g}$ ), dry mass of the stem (DMStem $-\mathrm{g}$ ), and total dry mass (DMTotal $-\mathrm{g}$ ), assessed at 60 days after spraying ripeners.

\begin{tabular}{llllllll}
\hline & \multicolumn{7}{c}{ Glyphosate } \\
\cline { 2 - 8 } Conc. & Diam & Height & N. Leaves & L. Area & DMLeaf & DMStem & DMTotal \\
\hline $0 \%$ & 8.88 & 35.0 & 16.4 & 594.4 & $6.31 \mathrm{ab}$ & 6.82 & 13.1 \\
$5 \%$ & 8.78 & 38.2 & 18.2 & 596.0 & $6.17 \mathrm{ab}$ & 7.40 & 13.5 \\
$15 \%$ & 8.25 & 40.0 & 16.6 & 676.5 & $6.91 \mathrm{a}$ & 7.12 & 14.0 \\
$30 \%$ & 9.42 & 39.5 & 15.8 & 692.3 & $7.36 \mathrm{a}$ & 7.46 & 14.8 \\
$45 \%$ & 8.23 & 38.3 & 20.1 & 539.4 & $5.00 \mathrm{~b}$ & 6.67 & 12.1 \\
$60 \%$ & 8.82 & 33.6 & 21.6 & 564.7 & $6.08 \mathrm{ab}$ & 6.59 & 13.2 \\
\hline $\mathrm{F}($ Conc.) & $1.57^{\text {ns }}$ & $2.27^{\text {ns }}$ & $1.28^{\text {ns }}$ & $2.10^{\text {ns }}$ & $4.11^{* *}$ & $1.20^{\text {ns }}$ & $2.34^{\text {ns }}$ \\
CV (\%) & 8.56 & 11.5 & 17.4 & 13.5 & 15.3 & 14.5 & 12.2 \\
\hline & & & \multicolumn{5}{c}{ Sulfometuron-methyl } \\
Conc. & Diam & Height & N. Leaves & L. Area & DMLeaf & DMStem & DMTotal \\
\hline $0 \%$ & $8.88 \mathrm{a}$ & $35.0 \mathrm{ab}$ & $16.4 \mathrm{~d}$ & 594.4 & 6.31 & 6.82 & 13.1 \\
$5 \%$ & $8.90 \mathrm{a}$ & $40.4 \mathrm{a}$ & $23.8 \mathrm{~d}$ & 607.0 & 5.73 & 6.07 & 11.8 \\
$15 \%$ & $7.58 \mathrm{~b}$ & $30.9 \mathrm{bc}$ & $42.1 \mathrm{c}$ & 609.9 & 6.25 & 6.54 & 12.7 \\
$30 \%$ & $8.38 \mathrm{ab}$ & $37.6 \mathrm{ab}$ & $42.6 \mathrm{c}$ & 688.4 & 6.43 & 6.31 & 12.7 \\
$45 \%$ & $8.78 \mathrm{ab}$ & $35.2 \mathrm{ab}$ & $51.7 \mathrm{~b}$ & 654.5 & 7.04 & 6.84 & 13.8 \\
$60 \%$ & $7.76 \mathrm{ab}$ & $27.9 \mathrm{c}$ & $63.6 \mathrm{a}$ & 673.6 & 6.67 & 5.62 & 12.3 \\
\hline $\mathrm{F}($ Conc.) & $3.77^{* *}$ & $7.11^{* *}$ & $71.0^{* *}$ & $2.10^{\text {ns }}$ & $1.22^{\text {ns }}$ & $1.20^{\text {ns }}$ & $2.34^{\text {ns }}$ \\
CV (\%) & 8.56 & 11.5 & 17.4 & 13.5 & 15.3 & 14.5 & 12.2 \\
\hline
\end{tabular}

Means followed by the same letter (column) do not differ from each other by the Tukey test at $5 \%$ of probability. ${ }^{* *}=$ significant value at $1 \%$ of probability by the $\mathrm{F}$ test. ${ }^{\mathrm{ns}}=$ value not significant at $5 \%$ of probability by the $\mathrm{F}$ test. $\mathrm{CV}=$ Coefficient of variation. Conc. $=$ Ripener concentration.

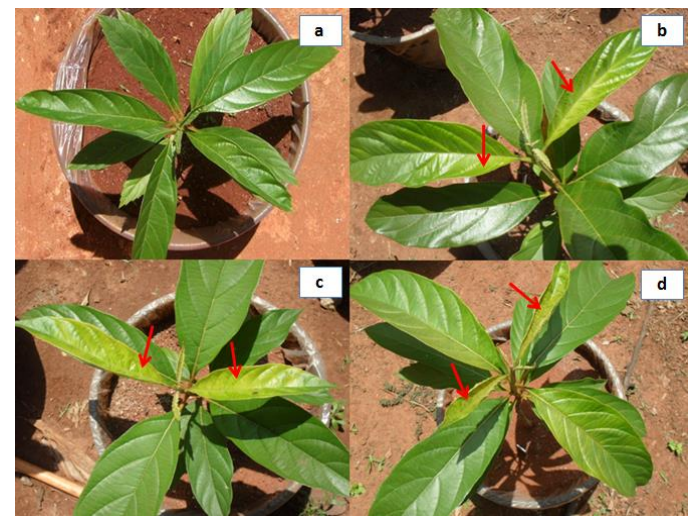

Fig 1. Citharexylum myrianthum, at 7 days after the application, with chlorosis (arrows) in the first pair of totally expanded leaves,

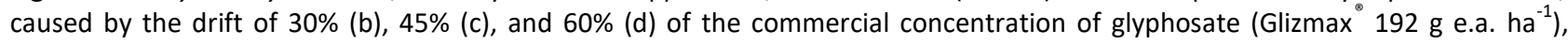
compared to the control treatment (a).

Table 2. Effect of different concentrations of glyphosate (Glizmax $192 \mathrm{~g}$ e.a. ha ${ }^{-1}$ ) and sulfometuron-methyl (Curavial $15 \mathrm{~g}$ e.a. ha $\left.{ }^{1}\right)$ to Citharexylum myrianthum on chlorophyll a fluorescence $\left(F_{\mathrm{v}} / F_{\mathrm{m}}\right)$, total relative chlorophyll content $(\mathrm{Chlorphyll}-\mathrm{UR})$, net $\mathrm{CO}_{2}$ assimilation rate $\left(A-\mu \mathrm{mol} \mathrm{CO} \mathrm{m}^{-2} \mathrm{~s}^{-2}\right)$, stomatal conductance $\left(g_{\mathrm{s}}-\mathrm{mol} \mathrm{H}_{2} \mathrm{O} \mathrm{m} \mathrm{s}^{-2}\right)$, internal $\mathrm{CO}_{2}$ concentration $\left(C_{\mathrm{i}}-\mu \mathrm{mol} \mathrm{CO}_{2} \mathrm{~mol}^{-1}\right)$, and transpiration rate $\left(E-\mathrm{mmol} \mathrm{H}_{2} \mathrm{O} \mathrm{m} \mathrm{s}^{-2}\right)$, assessed at 07 days after spraying ripeners.

\begin{tabular}{|c|c|c|c|c|c|c|}
\hline \multirow[b]{2}{*}{ Conc. } & \multicolumn{6}{|c|}{ Glyphosate } \\
\hline & $\begin{array}{l}F_{\mathrm{v}} / F_{\mathrm{m}} \\
\text { (07 DAA) }\end{array}$ & $\begin{array}{l}\text { Chlorophyll } \\
\text { (07 DAA) }\end{array}$ & $\begin{array}{l}A \\
\text { (07 DAA) }\end{array}$ & $\begin{array}{l}g_{\mathrm{s}} \\
\text { (07 DAA) }\end{array}$ & $\begin{array}{l}C_{\mathrm{i}} \\
\text { (07 DAA) }\end{array}$ & $\begin{array}{l}E \\
\text { (07 DAA) }\end{array}$ \\
\hline $0 \%$ & $0.760 \mathrm{ab}$ & 48.7 & $8.11 \mathrm{~b}$ & $0.256 \mathrm{bc}$ & $263.2 \mathrm{a}$ & 2.99 \\
\hline $5 \%$ & $0.755 a b$ & 55.0 & $8.29 \mathrm{~b}$ & $0.223 \mathrm{~cd}$ & $241.8 b$ & 2.87 \\
\hline $15 \%$ & $0.768 a$ & 53.4 & $9.08 \mathrm{ab}$ & $0.255 \mathrm{bc}$ & $263.3 \mathrm{a}$ & 3.21 \\
\hline $30 \%$ & $0.712 \mathrm{bc}$ & 53.5 & $9.75 \mathrm{a}$ & $0.310 \mathrm{a}$ & $276.0 \mathrm{a}$ & 3.36 \\
\hline $45 \%$ & $0.690 \mathrm{c}$ & 53.5 & $9.73 \mathrm{a}$ & $0.280 \mathrm{ab}$ & $274.4 \mathrm{a}$ & 3.20 \\
\hline $60 \%$ & $0.696 \mathrm{c}$ & 53.5 & $8.92 \mathrm{ab}$ & $0.188 \mathrm{~d}$ & $260.7 \mathrm{ab}$ & 3.01 \\
\hline $\mathrm{F}$ (Conc.) & $8.77^{* *}$ & $0.74^{\text {ns }}$ & $6.06^{* *}$ & $11.4^{* *}$ & $6.19 * *$ & $1.04^{\text {ns }}$ \\
\hline \multirow[t]{2}{*}{ CV (\%) } & 4.01 & 8.23 & 8.55 & 14.9 & 4.79 & 17.5 \\
\hline & \multicolumn{6}{|c|}{ Sulfometuron-methyl } \\
\hline Conc. & $\begin{array}{l}F_{\mathrm{v}} / F_{\mathrm{m}} \\
(07 \mathrm{DAA})\end{array}$ & $\begin{array}{l}\text { Chlorophyll } \\
\text { (07 DAA) }\end{array}$ & $\begin{array}{l}A \\
\text { (07 DAA) }\end{array}$ & $\begin{array}{l}g_{\mathrm{s}} \\
\text { (07 DAA) }\end{array}$ & $\begin{array}{l}C_{\mathrm{i}} \\
\text { (07 DAA) }\end{array}$ & $\begin{array}{l}E \\
\text { (07 DAA) }\end{array}$ \\
\hline $0 \%$ & $0.760 \mathrm{a}$ & 48.7 & $8.11 \mathrm{ab}$ & $0.256 a$ & $263.2 \mathrm{a}$ & $2.99 a$ \\
\hline $5 \%$ & $0.698 \mathrm{~b}$ & 56.0 & $8.32 \mathrm{a}$ & $0.187 \mathrm{~b}$ & $253.5 \mathrm{ab}$ & $2.30 \mathrm{ab}$ \\
\hline $15 \%$ & $0.695 \mathrm{~b}$ & 51.8 & $8.18 \mathrm{ab}$ & $0.145 \mathrm{bc}$ & $236.0 \mathrm{bc}$ & $1.74 \mathrm{bc}$ \\
\hline $30 \%$ & $0.686 \mathrm{~b}$ & 51.7 & $7.07 \mathrm{bc}$ & $0.139 \mathrm{bc}$ & $232.7 c$ & $1.33 \mathrm{c}$ \\
\hline $45 \%$ & $0.682 \mathrm{~b}$ & 52.2 & $6.15 \mathrm{~cd}$ & $0.122 c$ & $231.2 \mathrm{c}$ & $1.37 \mathrm{c}$ \\
\hline $60 \%$ & $0.685 \mathrm{~b}$ & 57.3 & $5.23 \mathrm{~d}$ & $0.113 c$ & $230.4 \mathrm{c}$ & $1.20 \mathrm{c}$ \\
\hline $\mathrm{F}$ (Conc.) & $6.39 * *$ & $0.74^{\text {ns }}$ & $20.2^{* *}$ & $18.0^{* *}$ & $7.81^{* *}$ & $15.5^{* *}$ \\
\hline CV (\%) & 4.01 & 8.23 & 8.55 & 14.9 & 4.79 & 17.5 \\
\hline
\end{tabular}

Means followed by the same letter (column) do not differ from each other by the Tukey test at $5 \%$ of probability. $* *=$ significant value at $1 \%$ of probability by the $\mathrm{F}$ test ${ }^{n s}=$ value not significant at $5 \%$ of probability by the $\mathrm{F}$ test. $\mathrm{CV}=$ Coefficient of variation. DAA $=$ Days after the application. Conc. = Ripener concentration. 


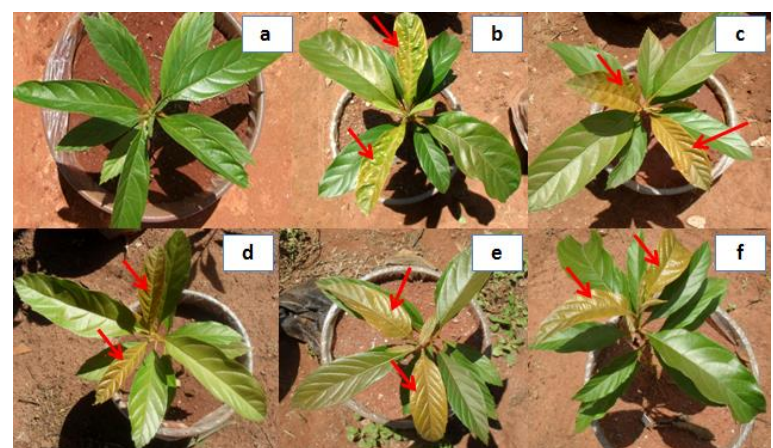

Fig 2. Citharexylum myrianthum, at 7 days after the application, with yellow-bronze coloring (arrows) in the first pair of totally expanded leaves, caused by the drift of $5 \%$ (b), $15 \%$ (c), $30 \%$ (d), $45 \%$ (e), and $60 \%$ (f) of the commercial concentration of sulfometuron-methyl (Curavial $15 \mathrm{~g}$ e.a. $\mathrm{ha}^{-1}$ ), compared to the control treatment (a).

Table 3. Effect of different concentrations of glyphosate (Glizmax $192 \mathrm{~g}$ e.a. ha ${ }^{-1}$ ) and sulfometuron-methyl (Curavial $15 \mathrm{~g}$ e.a. ha $\left.{ }^{1}\right)$ to Citharexylum myrianthum on chlorophyll a fluorescence $\left(F_{\mathrm{v}} / F_{\mathrm{m}}\right)$, total relative chlorophyll content (Chlorphyll - UR), net assimilation rate $\left(A-\mu \mathrm{mol} \mathrm{CO} \mathrm{m}^{-2} \mathrm{~s}^{-2}\right)$, stomatal conductance $\left(g_{\mathrm{s}}-\mathrm{mol} \mathrm{H}_{2} \mathrm{O} \mathrm{m} \mathrm{m}^{-2}\right)$, internal $\mathrm{CO}_{2}$ concentration $\left(C_{\mathrm{i}}-\mu \mathrm{mol} \mathrm{CO}_{2}\right.$ mol $\left.{ }^{-1}\right)$, and transpiration rate $\left(E-\mathrm{mmol} \mathrm{H}_{2} \mathrm{O} \mathrm{m} \mathrm{s}^{-2}\right)$, assessed at 30 days after spraying ripeners.

\begin{tabular}{|c|c|c|c|c|c|c|}
\hline \multirow[b]{2}{*}{ Conc. } & \multicolumn{6}{|c|}{ Glyphosate } \\
\hline & $\begin{array}{l}F_{\mathrm{v}} / F_{\mathrm{m}} \\
(30 \mathrm{DAA})\end{array}$ & $\begin{array}{l}\text { Chlorophyll } \\
\text { (30 DAA) }\end{array}$ & $\begin{array}{l}A \\
(30 \mathrm{DAA})\end{array}$ & $\begin{array}{l}g_{\mathrm{s}} \\
(30 \mathrm{DAA})\end{array}$ & $\begin{array}{l}C_{\mathrm{i}} \\
\text { (30 DAA) }\end{array}$ & $\begin{array}{l}E \\
\text { (30 DAA) }\end{array}$ \\
\hline $0 \%$ & 0.776 & 47.2 & 9.02 & $0.265 \mathrm{c}$ & $266.5 \mathrm{abc}$ & $2.60 \mathrm{c}$ \\
\hline $5 \%$ & 0.783 & 48.5 & 9.16 & $0.288 \mathrm{bc}$ & $257.5 \mathrm{c}$ & $2.97 b c$ \\
\hline $15 \%$ & 0.780 & 50.7 & 9.54 & $0.300 \mathrm{abc}$ & $272.7 a b c$ & $3.50 \mathrm{a}$ \\
\hline $30 \%$ & 0.787 & 50.8 & 9.67 & $0.354 \mathrm{a}$ & $280.1 \mathrm{a}$ & $3.61 \mathrm{a}$ \\
\hline $45 \%$ & 0.758 & 53.1 & 9.88 & $0.318 a b c$ & $277.1 \mathrm{ab}$ & $3.47 \mathrm{ab}$ \\
\hline $60 \%$ & 0.748 & 53.5 & 9.18 & $0.328 \mathrm{ab}$ & $263.0 \mathrm{bc}$ & $3.31 \mathrm{ab}$ \\
\hline $\mathrm{F}$ (Conc.) & $0.80^{\text {ns }}$ & $1.90^{\mathrm{ns}}$ & $1.88^{\mathrm{ns}}$ & $4.29 * *$ & $4.82^{* *}$ & $10.1^{* *}$ \\
\hline CV (\%) & 4.56 & 6.63 & 6.88 & 13.6 & 3.63 & 10.3 \\
\hline \multicolumn{7}{|c|}{ Sulfometuron-methyl } \\
\hline Conc. & $\begin{array}{l}F_{\mathrm{v}} / F_{\mathrm{m}} \\
(30 \mathrm{DAA})\end{array}$ & $\begin{array}{l}\text { Chlorophyll } \\
\text { (30 DAA) }\end{array}$ & $\begin{array}{l}A \\
\text { (30 DAA) }\end{array}$ & $\begin{array}{l}g_{\mathrm{s}} \\
\text { (30 DAA) }\end{array}$ & $\begin{array}{l}C_{\mathrm{i}} \\
\text { (30 DAA) }\end{array}$ & $\begin{array}{l}E \\
(30 \mathrm{DAA})\end{array}$ \\
\hline $0 \%$ & 0.766 & 47.2 & $9.02 \mathrm{a}$ & $0.265 \mathrm{a}$ & 266.5 a & $2.60 \mathrm{ab}$ \\
\hline $5 \%$ & 0.784 & 56.4 & $8.72 \mathrm{a}$ & $0.253 a b$ & $259.0 \mathrm{a}$ & $2.70 \mathrm{a}$ \\
\hline $15 \%$ & 0.786 & 56.9 & $8.97 \mathrm{a}$ & $0.233 a b$ & $260.1 \mathrm{a}$ & $2.64 a b$ \\
\hline $30 \%$ & 0.791 & 56.8 & $8.53 \mathrm{a}$ & $0.246 a b$ & $264.7 \mathrm{a}$ & $2.61 \mathrm{ab}$ \\
\hline $45 \%$ & 0.792 & 56.6 & $7.30 \mathrm{~b}$ & $0.196 \mathrm{~b}$ & $264.3 \mathrm{a}$ & $2.28 a b$ \\
\hline $60 \%$ & 0.790 & 59.6 & $6.69 \mathrm{~b}$ & $0.190 \mathrm{~b}$ & $242.1 \mathrm{~b}$ & $2.14 \mathrm{~b}$ \\
\hline $\mathrm{F}$ (Conc.) & $0.80^{\text {ns }}$ & $1.90^{\text {ns }}$ & $15.5^{* *}$ & $4.14^{* *}$ & $5.19^{* *}$ & $3.54 * *$ \\
\hline CV (\%) & 4.56 & 6.63 & 6.88 & 13.6 & 3.63 & 10.3 \\
\hline
\end{tabular}

Means followed by the same letter (column) do not differ from each other by the Tukey test at $5 \%$ of probability. ${ }^{* *}=$ significant value at $1 \%$ of probability by the $\mathrm{F}$ test. ${ }^{\mathrm{ns}}=$ value not significant at $5 \%$ of probability by the $\mathrm{F}$ test. $\mathrm{CV}=$ Coefficient of variation. DAA $=$ Days after the application. Conc. = Ripener concentration.

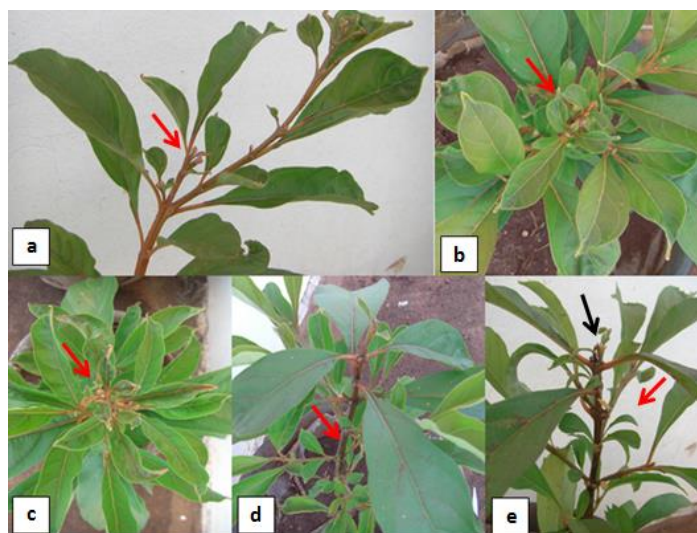

Fig 3. Detail of the visual symptoms of phytointoxication at 60 days after the application of sulfometuron-methyl in Citharexylum myrianthum plants treated with $5 \%$ (a), $15 \%$ (b), $30 \%$ (c) $45 \%$ (d), and $60 \%$ (e) of the commercial dose of sulfometuron-methyl (Curavial $15 \mathrm{~g}$ e.a. $\mathrm{ha}^{-1}$ ). Super sprout is observed (red arrow) in all of the treatments and death of the apical meristem (black arrow) for the highest concentration (e). 
Table 4. Effect of different concentrations of glyphosate (Glizmax $192 \mathrm{~g}$ e.a. ha ${ }^{-1}$ ) and sulfometuron-methyl (Curavial $15 \mathrm{~g}$ e.a. ha $\left.{ }^{1}\right)$ to Citharexylum myrianthum on chlorophyll a fluorescence $\left(F_{\mathrm{v}} / F_{\mathrm{m}}\right)$, total relative chlorophyll content $(\mathrm{Chlorphyll}-\mathrm{UR})$, net $\mathrm{CO}_{2}$

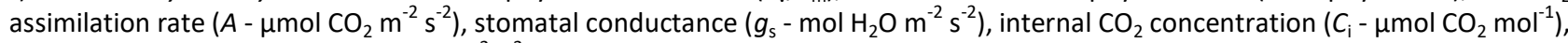
and transpiration rate $\left(E-\mathrm{mmol} \mathrm{H}_{2} \mathrm{O} \mathrm{m} \mathrm{s}^{-2}\right)$, assessed at 60 days after spraying ripeners.

\begin{tabular}{|c|c|c|c|c|c|c|}
\hline \multirow[b]{2}{*}{ Conc. } & \multicolumn{6}{|c|}{ Glyphosate } \\
\hline & $\begin{array}{l}F_{\mathrm{v}} / F_{\mathrm{m}} \\
(60 \mathrm{DAA})\end{array}$ & $\begin{array}{l}\text { Chlorophyll } \\
\text { (60 DAA) }\end{array}$ & $\begin{array}{l}A \\
(60 \mathrm{DAA})\end{array}$ & $\begin{array}{l}g_{\mathrm{s}} \\
\text { (60 DAA) }\end{array}$ & $\begin{array}{l}C_{\mathrm{i}} \\
(60 \mathrm{DAA})\end{array}$ & $\begin{array}{l}E \\
(60 \mathrm{DAA})\end{array}$ \\
\hline $0 \%$ & 0.768 & 45.6 & 9.70 & 0.350 & 276.1 & 3.35 \\
\hline $5 \%$ & 0.789 & 44.9 & 9.44 & 0.320 & 270.3 & 3.16 \\
\hline $15 \%$ & 0.765 & 47.2 & 9.85 & 0.380 & 280.5 & 3.59 \\
\hline $30 \%$ & 0.747 & 47.6 & 9.91 & 0.395 & 283.5 & 3.63 \\
\hline $45 \%$ & 0.771 & 47.7 & 9.87 & 0.363 & 278.6 & 3.60 \\
\hline $60 \%$ & 0.766 & 47.3 & 9.34 & 0.351 & 273.8 & 3.35 \\
\hline F (Conc.) & $1.49^{\text {ns }}$ & $1.99^{\text {ns }}$ & $0.12^{\text {ns }}$ & $0.71^{\text {ns }}$ & $0.23^{\text {ns }}$ & $0.61^{\mathrm{ns}}$ \\
\hline \multirow[t]{3}{*}{ CV (\%) } & 3.68 & 8.30 & 9.12 & 19.0 & 4.17 & 11.5 \\
\hline & \multicolumn{6}{|c|}{ Sulfometuron-methyl } \\
\hline & $\begin{array}{l}F_{\mathrm{v}} / F_{\mathrm{m}} \\
(60 \mathrm{DAA})\end{array}$ & $\begin{array}{l}\text { Chlorophyll } \\
\text { (60 DAA) }\end{array}$ & $\begin{array}{l}A \\
(60 \mathrm{DAA})\end{array}$ & $\begin{array}{l}g_{\mathrm{s}} \\
\text { (60 DAA) }\end{array}$ & $\begin{array}{l}C_{\mathrm{i}} \\
(60 \mathrm{DAA})\end{array}$ & $\begin{array}{l}E \\
(60 \mathrm{DAA})\end{array}$ \\
\hline $0 \%$ & 0.768 & 45.6 & 9.70 & 0.350 & 276.1 & 3.35 \\
\hline $5 \%$ & 0.787 & 53.1 & 9.30 & 0.336 & 265.2 & 3.19 \\
\hline $15 \%$ & 0.773 & 55.3 & 9.66 & 0.315 & 276.5 & 3.22 \\
\hline $30 \%$ & 0.799 & 50.0 & 9.65 & 0.336 & 279.1 & 3.31 \\
\hline $45 \%$ & 0.784 & 50.1 & 9.75 & 0.328 & 281.8 & 3.61 \\
\hline $60 \%$ & 0.773 & 51.3 & 8.82 & 0.318 & 270.3 & 3.18 \\
\hline F (Conc.) & $1.49^{\text {ns }}$ & $1.99^{\text {ns }}$ & $0.12^{\mathrm{ns}}$ & $0.71^{\text {ns }}$ & $0.23^{\text {ns }}$ & $0.61^{\text {ns }}$ \\
\hline CV (\%) & 3.68 & 8.30 & 9.12 & 19.0 & 4.17 & 11.5 \\
\hline
\end{tabular}

Means followed by the same letter (column) do not differ from each other by the Tukey test at $5 \%$ of probability. ${ }^{\text {ns }}=$ value not significant at $5 \%$ of probability by the $F$ test. $\mathrm{CV}=$ Coefficient of variation. $\mathrm{DAA}=$ Days after the application. Conc. $=$ Ripener concentration.

difference for $60 \%$ and $5 \%$ doses, and plants treated with $5 \%$ presenting the lowest concentrations of internal carbon in the leaves (Tables 3).

In the net assimilation rate, only the two highest concentrations of sulfometuron-methyl caused reduction (22.3\%) (Table 3). For stomatal conductance, again the only two treatments that differed from the control were $45 \%$ and $60 \%$, with only the $60 \%$ treatment causing reduction in the concentration of internal carbon compared to the other treatments. Regarding transpiration rate, plants from the $5 \%$ treatment showed $26.1 \%$ higher value than the $60 \%$ treatment (Table 3).

In the evaluation for gas exchanges, quantum efficiency of photosystem II, and total chlorophyll content, carried out at the end of the experimental period (60 DAA), it was possible to observe total recovery of plants' photosynthetic apparatus, independent of which product was applied, with no significant difference being found for the characteristics evaluated (Table 4).

\section{Discussion}

Despite not carrying out any evaluation of phytotoxicity scores, $C$. myrianthum plants showed symptoms of chlorisis in the first expanded leaves of plants treated with the 30\% to $60 \%$ concentrations at 7 DAA, with severity of the symptom being proportional to the increase in concentration. Similar symptoms were also observed in other tree species for concentrations equal to or higher than 86.4 g e.a. ha $^{-1}$, such as Eucalyptus urophylla and E. grandis, (Tuffi Santos et al., 2006), Genipa americana (Gusmão et al., 2011), Aspidosperma desmanthum (Rondon Neto et al., 2011), Hevea brasiliensis (Farias et al., 2012), and also in monocotyledon plants such as sorghum and corn for concentrations of $172 \mathrm{~g}$ e.a. ha ${ }^{-1}$ (Magalhães et al., $2001 \mathrm{a}$, b). Such damage is caused by the degradation of chloroplasts and also by inhibition of chloropyll formation, a common result observed in plants treated with glyphosate (Lee, 1981).
According to Vidal (1997), glyphosate can affect chlorophyll, since this molecule combines to the EPSP-S3P enzymatic complex in the chloroplast, inhibiting the synthesis of essential amino acids. This herbicide also causes indirect effects such as reducing RuBisCo enzymatic activity (Ahsan et al., 2008) and also disorganizing the photosynthetic apparatus (grain and intergrain), depending on the concentration used (María et al., 2005). This may have caused, for example, low values for quantum efficiency of photosystem II (PSII) in the evaluation carried out at 07 DAA (Table 2) in the plants that received the two highest concentrations tested. Thus, it is worth mentioning that the $F_{\mathrm{v}} / F_{\mathrm{m}}$ fluorescence ratio is important physiological characteristic used in studies related to the different types of stresses as it is indicator of plants' photosynthetic capacity (Krause and Weis, 1991).

Variations in physiological responses were also observed by Pereira et al. (2010) at 7 days after spraying different concentrations of glyphosate to $E$. grandis. On this occasion, the authors found $22 \%$ reduction in transpiration and $18 \%$ reduction in the stomatal conductance of eucalyptus when $120 \mathrm{~g}$ e.a. ha ${ }^{-1}$ of the Scout commercial formula was sprayed. However, despite there also being variation in physiological responses in this study at 07 DAA (Table 2), none of concentrations tested was enough to negatively affect the biometric characteristics of $C$. myrianthum, since no treatment differed from the control (Table 1). This is probably due to the fact that plants' photosynthetic apparatus completely recovered within 60 days after application, as shown in Table 4. Velini et al. (2008) observed positive effect of low concentrations of glyphosate in some tree species, with $68 \%$ increase in total dry mass in $E$. grandis and 22\% increase in Pinus caribea.

The positive effect resulting from low concentrations of originally toxic compounds is characterized as "hormesis" (Belz and Duke, 2014) and was also observed in other tree species and with other chemical products (Velini et al., 2008; Pereira et al., 2013; Pires et al., 2013; Correia and Villela, 2015). However, Belz and Duke (2014) note that the 
observation or not of a hormetic effect is directly related with climate conditions under which the experiment is conducted, the species or clone used, the stage of plant development, and also the period between the product application and the final evaluation carried out; thus explaining the fact that no positive effect has been observed of sub-concentrations of glyphosate on the initial development of $C$. myrianthum.

For the sulfometuron-methyl, visual symptoms of phytointoxication were also observed at 7 DAA, with all of the concentrations applied causing yellow-bronze coloring in the first totally expanded leaves. From 15\% concentrations onwards there was a loss of apical dominance (due to the death of apical meristem) and lateral leaf growth, and the higher the concentration, the greater the number of leaves (Table 1). As a result, plants grew less in height. Similar phytotoxic effects were also reported for $E$. urograndis (Correia and Villela, 2015).

This response may be related to this ripener's mode of action, which is inhibitor of ALS (acetolactate-synthase), belongs to the sulfonylurea chemical group and affects the synthesis of some essential amino acids (Cox, 2002; Zhou et al., 2007). As observed by Meschede et al. (2011), applying this product can interfere with photosynthesis by reducing the amount of carotenoids in leaves. This effect was also observed in this study, in which all of the applied concentrations differed from the control for quantum efficiency of the PSII at 07 DAA, and the two highest concentrations differed from the control in the gas exchange evaluations on the same date (Table 2).

Maxwell and Johnson (2000) note that normal values for quantum efficiency of PSII can vary between 0.850 and 0.750. Therefore, values within this range prove the efficiency of luminous energy capture by the reaction centers of this photosystem, which will result in the transport of electrons via PSII (Krause and Weis, 1991). Thus, values below this range of variation are taken as indications of stress, causing reductions in the plant's photosynthetic potential.

Despite quantum efficiency of PSII recovering in the subsequent evaluations, it is possible to note that at 30 DAA there is still not total recovery of photosynthetic apparatus of C. myrianthum, since the two highest concentrations presented lower values for net $\mathrm{CO}_{2}$ assimilation rate, stomatal conductance, and internal carbon for highest concentration (Table 3). Thus, this phenomenon may also have caused the shorter height observed at the end of the experimental period for the $60 \%$ treatment (Table 1). Moreover, despite the sulfometuron-methyl not having directly affected the total dry mass of $C$. myrianthum plants, they presented super sprout, which combined to delayed growth, in relation to the control, represent morphological alterations that can impair development (Table 1).

Phytotoxic effects of sulfometuron-methyl have also already been observed in other tree species. Geyer and Long (1998) note that this compound negatively affects the species Pinus strobus, $P$. sylvestris, $P$. nigra, and Juniperus virginiana. Correia and Villela (2015) observed that as the concentration of this ripener was increased, there was also reduction in the height of $E$. urograndis, as well as phytointoxication when exposed to $15 \mathrm{~g} \mathrm{ha}^{-1}$ concentrations of sulfometuron-methyl, while other species (cotton, peanut, soy, and bean) showed injuries that negatively reflected upon their development, as can be observed in the study from Correia and Leite (2012). Pires et al (2013) found positive effects in $E$. urograndis after applying low concentrations of this compound, with $14 \%$ gains in leaf area and $7 \%$ gains in total dry mass compared to the plants without application. Thus, varied responses found between the species are probably due to the different plant abilities to metabolize, translocate, and even compartmentalize sulfometuron-methyl (Correia and Leite, 2012).

\section{Materials and Methods}

\section{Plant materials and growth conditions}

The experiment was conducted in open and semi-controlled area, with all pots irrigated daily until reaching field capacity. During the experimental period, average air temperature of $23.1{ }^{\circ} \mathrm{C}$ (maximum of $30.1{ }^{\circ} \mathrm{C}$ and minimum of $17.3 \circ \mathrm{C}$ ) was recorded, with $65.8 \%$ relative air humidity and 252.8 hours of sunlight per month.

C. myrianthum seedlings with 18 months age had average of 10 leaves, stem diameter of $5.0 \mathrm{~mm}$ and $20 \mathrm{~cm}$ in height. As experimental units, we used pots $(5 \mathrm{~L})$ previously filled with a mixture of soil collected in the surface layer of a Dark Red Latosol - after determining fertility -, sand, and manure (3:1:1 v:v:v). After planting, plants were acclimated for 15 days before applying the ripeners.

\section{Treatments and experimental design}

Treatments consisted of a $6 \times 2$ factorial arrangement, corresponding to six concentrations and two chemical ripeners: glyphosate $(0.0 ; 9.6 ; 28.8 ; 57.6 ; 86.4$; and $115.2 \mathrm{~g}$ e.a. $\left.\mathrm{ha}^{-1}\right)$ and sulfometuron-methyl $(0.0 ; 0.75 ; 2.25 ; 4.50$; 6.75; and $9.00 \mathrm{~g} \mathrm{e.a.}^{-1} \mathrm{~h}^{-1}$ ). These doses are equivalent to 0 , $5,15,30,45$, and $60 \%$ of commercial concentration of Glizmax (192 g e.a. ha ${ }^{-1}$ ) and Curavial (15 g e.a. ha ${ }^{-1}$ ) recommended for sugarcane.

A randomized block design with six replications was used. The subdoses of ripeners (drift simulation) were applied 15 days after planting of seedlings byusing a $\mathrm{CO}_{2}$-pressurized backpack sprayer, equipped with XR 110.02 regulated for a volume of $200 \mathrm{~L} \mathrm{ha}^{-1}$ at 2.2 bar tank pressure. At the time of application, temperature was $27 \% \mathrm{C}$, with $60 \%$ cloud cover, $63.5 \%$ air humidity, and wind speed of $3 \mathrm{~km} \mathrm{~h}^{-1}$.

\section{Chl quantification and fluorescence}

At 07,30 , and 60 days after the application (DAA) of ripeners, the total relative chlorophyll content $(a+b)$ was measured using a portable chlorophyll meter (CFL 1030, Falker) and the potential quantum efficiency of the $\boldsymbol{a}$ chlorophyll $\left(F_{\mathrm{v}} / F_{\mathrm{m}}\right)$ was measured using a fluorometer (PEAMK2 Hansatech). These measurements were carried out in the second pair of totally expanded leaves $(n=5)$.

\section{Gas-exchange parameters}

Also at 07,30 , and $60 \mathrm{DAA}$, in the second pair of fully expanded leaves, the net $\mathrm{CO}_{2}$ assimilation rate $\left(A-\mu \mathrm{mol} \mathrm{CO}_{2}\right.$ $\left.\mathrm{m}^{-2} \mathrm{~s}^{-2}\right)$ was measured, as well as stomatal conductance $\left(g_{\mathrm{s}}-\right.$ $\left.\mathrm{mol} \mathrm{H} \mathrm{O} \mathrm{m}^{-2} \mathrm{~s}^{-2}\right)$, internal $\mathrm{CO}_{2}$ concentration $\left(C_{\mathrm{i}}-\mu \mathrm{mol} \mathrm{CO}_{2}\right.$ $\left.\mathrm{mol}^{-1}\right)$, and transpiration rate $\left(E-\mathrm{mmol} \mathrm{H}_{2} \mathrm{O} \mathrm{m}^{-2} \mathrm{~s}^{-2}\right)$, using a 
portable Infrared Gas Analyser (IRGA - LI 6400, LiCor, Lincoln, $\mathrm{NE}$, USA). For this, the photosynthetically active photon flux (quantum) was kept at $1500 \mu \mathrm{mol} \mathrm{m} \mathrm{m}^{-2}$, the relative air humidity and temperature in the sampling chamber at $85 \%$ and $25^{\circ} \mathrm{C}$, respectively, and the reference $\mathrm{CO}_{2}$ level at 400 $\mu \mathrm{mol} \mathrm{mol}{ }^{-1}$.

\section{Growth parameters}

At 7 and 60 DAA, morpho-physiological alterations in the plants resulting from experimental treatments were recorded photographically. At the end of the experimental period (60 DAA), the number of leaves, plants height (ruler graduated in millimeters), and stem diameter (digital pachymeter) were measured. Subsequently, leaves and stems of plants were separated and the leaf area was measured using a leaf area measurer (Li-Cor Inc., LI3000A, USA). The stems and leaves were placed in a forced air circulation oven at $70^{\circ} \mathrm{C}$ for 96 hours and the dry mass subsequently determined using analytical precision scale (Marte, AS2000C, Brazil).

\section{Statistical analysis}

Statistical analyses were performed using analysis of variance (ANOVA) and means were compared using the Tukey test at a $5 \%$ probability level. When the interaction was significant, we chose to consider the effect of concentrations within each ripener separately.

\section{Conclusion}

Both glyphosate and sulfometuron-methyl caused visual symptoms of phytointoxication in Citharexylum myrianthum, which were accompanied by alterations in gas exchange up until 30 days after application. At 60 days after the application, all plants treated with glyphosate presented recovery of photosynthetic capacity, with no detrimental effect on their initial development. Although plants had recovered their photosynthetic capacity at 60 days after the application of sulfometuron-methyl, there was reduction in the height of plants treated with the highest dose, combined to super sprout resulting from the death of the apical meristem. Thus, despite there not being any significant difference in total dry mass, the development of these plants was affected.

\section{Acknowledgments}

We thank Fundação de Amparo à Pesquisa do Estado de São Paulo (FAPESP) for the scholarship granted to M.A.G (2011/18370-3).

\section{References}

Ahsan N, Lee DG, Lee KW, Alam I, Lee SH, Bahk JD, Lee BH (2008) Glyphosate induced oxidative stress in rice leaves revealed by proteomic approach. Plant Physiol Bioch. 46(12):1062-1070.

Alvarez RC, Crusciol CAC, Nascente AS, Rodrigues JD, Habermann G (2012) Gas exchange rates, plant height, yield components, and productivity of upland rice as affected by plant regulators. Pesqui Agropecu Bras. 47(10):1455-1461.

Andef (2017) Associação nacional de defesa vegetal. Manual de boas práticas de aplicação de produtos fitossanitários. $12 \mathrm{p}$.

Belz RG, Duke SO (2014) Herbicides and plant hormesis. Pest Manag Sci. 70(5):698-707.

Conab (2017) Companhia nacional de abastecimento. Acompanhamento de safra brasileira: cana-de-açúcar, segundo levantamento, 2016/17. 72p.

Correia NM, Leite GJ (2012) Selectivity of the plant growth regulators trinexapac-ethyl and sulfometuron-methyl to cultivated species. Sci Agric. 69(3):194-200.

Correia NM, Villela GB (2015) Trinexapac-ethyl and sulfometuron-methyl selectivity to young eucalyptus plants. Planta Daninha. 33(2):259-266.

Cox C (2002) Sulfometuron-methyl (Oust). Journal of Pesticide Reform. 22(4):15-20.

Farias CCM, Rondon Neto RM, Yamashita OM, Farias CBM (2012) Efeitos de subconcentrações de glyphosate em plantas jovens de seringueira (Hevea brasiliensis Aubl.). Revista Brasileira de Herbicidas. 11(1):119-125.

Gelmini GA (1988) Herbicidas: indicações básicas. Campinas: Fundação Cargill. 334p.

Geyer WA, Long CF (1998) Weed management in plantings of tree and shrub seedlings with sulfometuron methyl (Oust). Transactions of the Kansas Academy of Science. 101:120-124.

Gusmão GA, Rondon Neto RM, Yamashita OM (2011) Deriva simulada de glyphosate em plantas jovens de jenipapo (Genipa americana L.). Revista Brasileira de Herbicidas. 10(1):13-19.

Jellinek S, Parris KM, Driscoll DA, Dwyer PD (2013) Are incentive programs working? landowner attitudes to ecological restoration of agricultural landscapes. J Environ Manage. 127:69-76.

Krause GH, Weis E (1991) Chlorophyll fluorescence and photosynthesis: the basics. Annu Rev Plant Phys. 42:313 349.

Lee T (1981) Effects of glyphosate on synthesis and degradation of chlorophyll in soybean and tobacco cells. Weed Res. 21:161-164.

Lorenzi H (1992) Árvores brasileiras. Nova Odessa: Plantarum. 384p.

Magalhães PC, Silva JB, Durães FOM, Karam D, Ribeiro LS (2001b) Efeito de concentrações reduzidas de glyphosate e paraquat simulando deriva na cultura do milho. Planta Daninha. 19(2):247-253.

Magalhães PC, Silva JB, Durães FOM, Karam D, Ribeiro LS (2001a) Efeito de concentrações reduzidas de glyphosate e paraquat simulando deriva na cultura do sorgo. Planta Daninha 19(2):255-262.

María N, Felipe M, Fernández-Pascual M (2005) Alterations induced by glyphosate on lupin photosynthetic apparatus and nodule ultra structure and some oxygen diffusion related proteins. Plant Physiol Bioch. 43:985-996.

Maxwell K, Johnson GN (2000) Chlorophyll fluorescence: a practical guide. J Exp Bot. 51(345):659-668.

Meschede DK, Velini ED, Carbonari CA, Silva JRM (2011) Alteração fisiológica da cana-de-açúcar pela aplicação de glyphosate e sulfumeturon-methyl. Planta Daninha. 29(2):413-419. 
Mori AS, Spies TA, Sudmeier-Rieux K, Andrade A (2013) Reframing ecosystem management in the era of climate change: issues and knowledge from forests. Biol Conserv. 165:115-127.

Nori J, Lescano JN, Illoldi-Rangel P, Frutos N, Cabrera MR, Leynaud GC (2013) The conflict between agricultural expansion and priority conservation areas: making the right decisions before it is too late. Biol Conserv. 159:507513.

Pereira FCM, Nepomuceno MP, Pires RN, Parreira MC, Alves PLCA (2013) Response of eucalyptus (Eucalyptus urograndis) plants at different doses of glyphosate. J Agri Sci. 5(1):66-74.

Pereira MRR, Rodrigues ACP, Costa NV, Martins D, Klar AE, Silva MR (2010) Glyphosate drift effect on some physiological features of eucalyptus plants. Interciencia. 35(4):279-283.

Pires RN, Pereira FCM, Nepomuceno MP, Alves PLCA (2013) Effects of the simulated drift of ripeners on Eucalyptus urograndis. J Agr Sci. 5(12):78-86.

Potapov P, Hansen MC, Laestadius L, Turubanosa S, Yahoshenko A, Thies C, Zhuravleva I, Komarova A, Minnemeyer S, Esipova E (2017) The last frontiers of wilderness: tracking loss of intact forest landscapes from 2000 to 2013. Science Advances. 3(1):1-13.
Rondon Neto RM, Benetti E, Yamashita OM, Gusmão G (2011) Fitotoxidade de peroba-mica (Aspidosperma desmanthum) submetidas à deriva de glyphosate. Revista Brasileira de Herbicidas. 10(2):103-109.

Tuffi Santos LD, Ferreira FA, Ferrreira LR, Duarte WM, Tiburcio RAS, Santos MV (2006) Intoxicação de espécies de eucalipto submetidas à deriva de glyphosate. Planta Daninha. 24(2):359-364.

asconcelos LEM, Aguiar OT (1982) A alimentação de Alouatta fusca Geof. (Primates, Cebidae). Paper presented at the congresso nacional sobre essências nativas, Campos do Jordão. Anais... São Paulo: UNIPRESS. Silvicultura em São Paulo. 16:1727-1730.

Velini ED, Alves E, Godoy MC, Meschede DK, Souza RT, Duke SO (2008) Glyphosate applied at low doses can stimulate plant growth. Pest Manag Sci. 64(4):489-496.

Viana RS, Silva PH, Mutton MA, Mutton MJR, Guimarães ER, Bento M (2008) Efeito da aplicação de maturadores químicos na cultura da cana de açúcar (Saccharum spp.) variedade SP81-3250. Acta Sci-Agron. 30(1):65-71.

Vidal RA (1997) Herbicidas: Mecanismos de ação e resistência de plantas. Porto Alegre: Palotti. 165p.

Zhou Q, Liu W, Zhang Y, Liu KK (2007) Action mechanisms of acetolactate synthase-inhibiting herbicides. Pestic Biochem Phys. 89(2):89-96. 